ISSN: 2683-2062

\title{
Bioethics and the relationship with Human Nutrition
}

\author{
Bioética y la relación con la Nutrición Humana
}

Romero, A. ${ }^{a}$, Sánchez, C. ${ }^{a}$, Salinas, $H .{ }^{a}$ y Solís, $A .{ }^{a}$, Omaña, A. ${ }^{b}$, Moya, A. ${ }^{c}$

\begin{abstract}
:
In a current society, professional ethics acquires a leading role and a fundamental importance in its development, and the training of future professionals, bioethics is the attempt of rational analysis of the duties that, as individuals and as members of a society, we have for ourselves or for others based on the nutritionist's ethical code consisting of six general principles: responsibility, professionalism, solidarity, respect, cooperation, legality. In the feeding of critical patients, in the nutritional support of terminal patients or different situations, ethical conflicts are frequently raised, so all their scientific knowledge and technical resources must be put into the performance of their profession.
\end{abstract}

\section{Keywords:}

Bioteiical, nutrition, ethics, nutritional support, code, duties

\section{Resumen:}

En una sociedad actual la ética profesional adquiere un protagonismo y una importancia fundamental en desarrollo de la misma, y la formación de los futuros profesionales, la bioética es el intento de análisis racional de los deberes que, como individuos y como miembros de una sociedad, tenemos para con nosotros mismos o para con los demás basándose en código ético del nutriólogo conformado por seis principios generales: la responsabilidad, profesionalidad, solidaridad, respeto, cooperación, legalidad. En la alimentación de pacientes críticos, en el soporte nutricional de pacientes terminales o distinta situación se plantean, con frecuencia, conflictos éticos por eso se debe poner todos sus conocimientos científicos y recursos técnicos en el desempeño de su profesión.

\section{Palabras Clave:}

Bioética, nutrición, ética, soporte nutricio, código, deberes

\section{INTRODUCTION}

In a society such as today, where recovery and education in values is being demanded, professional ethics takes on a leading role and a fundamental importance in its development, and the training of future professionals appears as one of the key issues.

The bioethics that according to Hottois was developed in the United States very close to medical ethics, focused on the individual and research in human beings, it has an antecedent as idea and word in 1927 (Molina, 2013). Since then, bioethics has had a short historical trajectory, but enriched with codes, declarations (Universal Declaration of Human Rights, Oslo Declaration, Helsinki-Tokyo Declaration, etc.), and principles that, as universally accepted minimum ethical guidelines, serve to take decisions in conflict resolution (Molina, 2013).
Human beings have equal and inalienable rights, an issue that guided the foundation of freedom, justice and peace in the world. Human dignity is the most evident point of approximation between bioethics and human rights, being the fundamental principle and the foundation of the theoretical construction in the two fields of knowledge (Gonclaves, Mayumi, Gómez, Da Cunha \& Corradi-Perini, 2018).

Bioethics can be understood as the discipline that studies the ethical aspects of MEDICINE and BIOLOGY in general and, by extension, the relationship of the human being with other living beings. It is the attempt of rational analysis of the duties

a. Alumno de la Licenciatura en Nutrición, Instituto Ciencias de la Salud. Universidada Autónoma del Estado de Hidalgo

b. Autor de Correspondencia, Universidad Autónoma del Estado de Hidalgo, Instituto de Ciencias de la Salud, ORCID: 0000-00028649-8617, Email: aomana@uaeh.edu.mx

c. Universidad Autónoma del Estado de Hidalgo, Instituto de Ciencias de la Salud, ORCID: 0000-0003-4448-2883, Email: amoya@uaeh.edu.mx 
that, as individuals and as members of a society, we have towards ourselves or towards others. In relation to biological sight, health and management of the body itself (Moreno, Álvarez, Wenden \& Lazaro, 2010). In today's society there is a growing tendency to link the good professional, only with experience and expertise, that is, in scientific and technical competence. In conclusion, today is considered a good professional who has expertise in the realization of a technique, not someone morally committed to society (Moreno, Alvarez, Wenden \& Lazaro, 2010).

\section{NUTRITIONIST'S CODE OF ETHICS}

The purpose of the Code of Professional Ethics is to sensitize the professional so that the professional practice is carried out in an environment of honesty, legitimacy and morality, for the benefit of society. Without prejudice to the legal norms set forth in the laws that regulate the exercise of the professions and the fulfillment of the obligations arising from contracts for the rendering of professional services, with the purpose of giving an ethical sense prevails in the spirit of those who have the privilege of possessing the knowledge and reaching this objective, one must contribute in solidarity to the reunion of our dignified, just and egalitarian life, but one must also be convinced of the commitment that is contracted upon receiving the investiture that accredits for the professional exercise (Mexican College of Nutritionists, 2015).

Every profession is a service to society, and this service cannot be performed in any way; for this reason, professions are endowed with ethical codes, which guide and regulate the conduct of their professionals. This task also affects new professions such as human nutrition and dietetics.

The creation of a code of ethics is primarily aimed at raising the standard of professional practice and good practice. The code will not be able to fulfil its purposes if it is not kept up to date with the changing needs of professional practice and the new situations created by social and scientific progress. The graduate in nutrition must acquire a serious and responsible commitment to society, which must be fulfilled through the code assumed, explicit, published and freely accepted by the nutrition professional who practices as such. Professionals voluntarily adopt this code that reflects the values and ethical principles that guide the profession, which also expose the commitments and obligations that the graduate in nutrition contracted to patients, and their practice of the profession, colleagues, other professionals and society in general (Asociación Argentina de Dietistas y Nutriólogos Dietistas, 2017).

The nutritionist's code of ethics is based on six general principles: responsibility, professionalism, solidarity, respect, cooperation, legality (Argentine Association of Dieticians and Nutritionists dieticians, 2017). Unlike legal norms, in the case of ethical norms, there is no punitive power for the State to sanction non-compliance. The observance of ethics depends exclusively on the will of those who have imposed for themselves, through self-conviction, the duty to comply with it. The will is totally autonomous and there is no one who can impose its fulfillment.
The will to adhere to an ethical code of conduct is determined by the value attributed and recognized to the reason of being of the norm, which is none other than the cultural and social good. Thus, the opinion or valuation of this good is indispensable to form the will, and to accept or reject the ethical norm and commit to comply with it (Mexican College of Nutritionists, 2015).

The standards of professional conduct include the provision of services and the application of knowledge, the development of professional practice and the application of research, the communication of professional knowledge and skills, the quality of professional practice and competence with professional responsibility (Borja Institute of Ethics, 2010).

\section{ETHICS IN THE EXERCISE OF NUTRITION}

The nutritionist must reflect and analyze in order to look for causes and consequences of the behaviors-customs in the work of his profession, and therefore, of the norms and moral values that sustain and legitimize them. In addition, ethics suggests, invites, proposes and recommends alternatives based on the ethical foundation and on the consequences of the act of caring. So that the norms, behaviors, customs and moral values change when the situation warrants it, or to continue in the same way and reinforce them when their repercussions are positive; always in the priority search for the good of the people they serve, the good of oneself and that of the other professionals with whom he/she performs his/her functions. Identifying this process as ethics enriches morals.

In this way, ethics invites the nutritionist to reflection strengthened with experiences, testimonies, observations, data, perceptions, interpretations and questionings, which are integral elements to provide the conditions for the study of reality, these being fundamental aspects in decision making and in the proposal for action (Celis, 2014).

\section{ETHICAL RECOMMENDATIONS FOR A NUTRITIONIST}

To be in solidarity with the people who are taken care of in their experiences of health and illness, avoiding to see them and to treat them as strange beings to achieve from the solidarity to find spaces of word with the purpose of recognizing the human dignity, autonomy and knowledge of the other.

Preserve and prioritize people's rights, promoting the recognition of health, nutrition and food as human rights. Advocating before the health system for the people who receive the service. Include the study of ethics and bioethics in undergraduate, graduate and continuing education, as a commitment of educational institutions, unions and professionals. Assuming the commitment not only to be a good nutritionist, but also a good nutritionist. 11

Procuring the right nutrition through good nutrition becomes one of the most important and effective tasks to promote and protect health, as well as to prevent disease. Many nonnutritional diseases require dietary changes; this is the field of dietotherapy. One of the great therapeutic revolutions of the twentieth century is the so-called "artificial" food that has improved the prognosis and facilitated the treatment of patients 
in critical conditions who died almost irremediably before (National Bioethics Commission, 2016).

Ethical decisions are present throughout clinical practice and also in the field of nutritional support. In the feeding of critical patients, in the nutritional support of terminal patients or in the situation of patients with a permanent vegetative state, ethical conflicts often arise6. One of the basic cares for the maintenance of life in the serious patient is hydration and nutrition. Nutritional support presents a wide range of clinical situations, so the choice of artificial nutrition (enteral and parenteral) in certain patients and/or situations must be preceded by ethical reflection, covering objective aspects, both medical, pharmaceutical and nursing. It is necessary to analyse the characteristics of the patient and the social, family and economic circumstances before advising or discouraging the establishment of such a nutritious-therapeutic procedure.

The quantity, variety and quality of parameters that must be examined in order to make an adequate decision, with respect to providing artificial nutrition, conditions complexity as they are parameters or variables that provide clinical, biochemical, anthropometric, social and bioethical information, are criteria that refer to the patient's decision, family, social and economic factors 5 .

\section{PROVISION OF SERVICES AND APPLICATION OF KNOWLEDGE}

The professional of human nutrition and dietetics will guarantee a correct provision or rendering of services, as well as the adequate application of specific knowledge through the fulfillment of duties (Borja Institute of Ethics, 2010).

\section{DUTIES OF THE NUTRITIONIST}

It is essential to train students in both values and ethics, since as health professionals they will have a great responsibility in the state of health of the individual and/or the community ${ }^{8}$.

The nutritionist must put all his scientific knowledge and technical resources in the performance of his profession, conducted by values such as justice, honesty, honesty, diligence, loyalty, respect, formality, discretion, honorability, responsibility, sincerity, dignity. $\mathrm{He} / \mathrm{She}$ will be responsible for matters when he/she has the capacity to deal with them and will indicate the scope of his/her work and inherent limitations.

$\mathrm{He} / \mathrm{she}$ must maintain strict confidentiality of the information provided by the patient, as well as respect at all times the human rights of his/her client, colleagues and society in general.

He/she should also offer his/her professional services according to their scientific and technical capacity.

When the nutritionist prescribes a diet, he will follow up until he considers it finished according to his own criteria or according to the indications of the other professionals in charge.He/she will educate and inform any individual within the professional context.Also, he/she will transmit information only of his/her competence and without adopting an exclusively advertising attitude.Finally,he/she will protect any person or community when his/her health and safety are threatened by dishonest, incompetent and/or illegal practices ${ }^{3}$.

\section{ETHICS IN THE TREATMENT OF OBESITY}

Obesity is a disease that affects a large number of the world's population. Patients are interested in treatment that is effective, simple and fast. This includes inappropriate medication or dietary supplements, surgery or unbalanced diets.

Is it really ethical to prescribe miracle products? We must remember that the nutritionist must put the well-being, health and life of his patient before any other interest, we must avoid choosing the paths that are easier and simpler, because the health of the patient is in the middle. It is very important that the health personnel in charge of treating obesity are able to explain the patient's condition and have goals that are realistic, without implying the patient's health. However, monitoring treatment is difficult, as many things can influence the patient to leave, such as lack of attachment, lack of motivation and despite the difficulties, health professionals must have a commitment to ensure that the patient has quality care (Flores, 2012).

\section{DIABETES AND ITS BIOETHICAL APPROACH}

Studies in our country document that in the last two decades the increase in cases of type 2 diabetes mellitus is up to ten times higher than in the 1980s. These same studies show that $2.4 \%$ of obese children developed the disease before the age of 30 . This scenario leads to the consideration of a bioethical approach for the development of strategies to improve adolescent health.

Being a vulnerable group, bioethics involves attention to the physical, psychological and social characteristics of this population. There are several bioethical models that address the positive development of adolescent health. One of them is the Pan American Health Organization's Regional Plan of Action for Adolescent Development and Health, which proposes actions in four axes:

1) quality education at the basic, middle and upper middle levels.

2) health of today's adolescents, focused on health services, counseling and health education.

3) adolescents promoting healthy futures, aimed at preadolescents in school settings.

4) adolescents as agents of change, focused on active participation in communities, mass media and thus youth empowerment (National Bioethics Commission, 2016) (Comisión Nacional de Bioética, 2016).

\section{HIGH BLOOD PRESSURE AND ETHICS}

The diagnosis of high blood pressure can give rise to ethical conflicts at five different stages of the process: at the time of providing the information, at the moment of indicating the diagnostic tests, at the time of carrying out the diagnostic tests, at the time of communicating the diagnosis and at the time of making subsequent decisions. With respect to information, it is clear that it must be considered as unethical behaviour, not to inform the risk of 
the tests available to diagnose it, whether due to simple professional negligence, to provide erroneous information on the risks of the tests, and to provide faulty or partial information on the usefulness of the same, it is also of special relevance to take into account the protection of patients with diminished autonomy as some authors point out where their physical or mental capacities are not optimal to make these decisions, the family in these cases can play an important role in strengthening this relationship and become a support both for the patient and for the doctor in these cases. ${ }^{10}$

\section{CONCLUSION}

Clinical nutrition develops its field of action in individual health care.

In this task health professionals are trained to promote the consumption of a healthy diet, which is characterized by providing the nutrients necessary to keep a person healthy. In this arduous task of food orientation, it is necessary to consider a series of variables proper to the culinary culture of the human being, such as the socioeconomic stratum, social, cultural and political conditions, to mention just a few. That is why, from this context, clinical nutritionology must observe bioethical principles. It is assumed that the praxis of nutriology cannot be left to anyone's discretion. On the contrary, a continuous education is required, beyond ideologies and prejudices, where it is possible for the nutritionist to be educated to educate, which leads to highlight the responsibility acquired by health professionals and those who form them.

\section{REFERENCES}

Molina, R. (2013). Bioethics: its principles and purposes, for a techno-scientific, multicultural and diverse world. Colombian Journal of Bioethics, 8(2), 18-37.

Gonçalves, E., Mayumi, I., Gomes, R., Da Cunha, T., \& Corradi-Perini C. (2018). Bioethics and the human right to adequate food in enteral nutrition therapy. Rev. Bioét. Bioét. Brasília. 26(2): 22-24.

Borja Institute of Ethics. (2010). Proposal for an ethical code in the profession of human nutrition and dietetics). Bioethics \& debate. 16(59), 3-23.

Argentine Association of Dietists and Nutritionists. Code of ethics. (2017). Available at: http://www.aadynd.org.ar/descargas/profesionaleslegales/código-etica-aadynd-1.pdf.

Jiménez, N. Bioethical approach to nutritional support. $3^{\mathrm{a}}$ ed. Mexico: ed. Trillas-SEFH.

Moreno J, Álvarez J, Wanden C, Lozano M. Glossary of frequent terms and expressions of Bioethics in the practice of Clinical Nutrition. April 2010; 25(5): 543548.

Flores, C. (2012). Ethics in the treatment of obesity. Clinical Nutrition and Hospital Dietetics. 32(2), 54-57.

Chiva, M., Lluch, J., Martín, J., Palau, A., Sánchez, A. \& Trescastro-López, E. (2015). Is professional ethics a luxury we can do without. Rev Esp Nutr Hum Diet. 19(3), 175-183.
National Bioethics Commission. Type 2 diabetes mellitus in adolescents: A priority in Mexican society. September 2016; 2(21):12-16.

Santana, S. \& Montero, R. (2015). Ethical dilemmas in the diagnosis of high blood pressure. Journal of NonCommunicable Diseases. 2 (4), 55- 56.

Celis, A. (2014). Ethical conflicts in the profession of nutritionist in Guatemala. Guatemala: Universidad Rafael Landívar/ Facultad de Ciencias de la Salud/ Licenciatura en Nutrición.

Mexican College of Nutritionists A.C. (2015). Nutriologist's Code of Professional Ethics. Available online: https://www.cmnutriologos.org/recursos/Codigo_de_et ica.pdf. Access date: 16/08/19. 